Article

\title{
Sustainable Allocation Model of Construction Workforce for Work Resumption during COVID-19
}

\author{
Layin Wang ${ }^{1, *}$, Dong Zhao ${ }^{2}\left(\mathbb{D}\right.$ and Yanqi Zhong ${ }^{3}$ \\ 1 School of Management, Xi'an University of Architecture \& Technology, Xi'an 710055, China \\ 2 Department of Civil \& Environmental Engineering, School of Planning, Design and Construction, \\ Michigan State University, East Lansing, MI 48824, USA; dzhao@msu.edu \\ 3 School of AnDe, Xi'an University of Architecture \& Technology, Xi'an 710311, China; \\ Chery10809@xauat.edu.cn \\ * Correspondence: wanglayin@xauat.edu.cn
}

check for

updates

Citation: Wang, L.; Zhao, D.; Zhong,

Y. Sustainable Allocation Model of

Construction Workforce for Work

Resumption during COVID-19.

Sustainability 2021, 13, 6481. https://

doi.org/10.3390/su13116481

Received: 19 April 2021

Accepted: 3 June 2021

Published: 7 June 2021

Publisher's Note: MDPI stays neutral with regard to jurisdictional claims in published maps and institutional affiliations.

Copyright: (C) 2021 by the authors Licensee MDPI, Basel, Switzerland. This article is an open access article distributed under the terms and conditions of the Creative Commons Attribution (CC BY) license (https:/ / creativecommons.org/licenses/by/ $4.0 /)$.

\begin{abstract}
COVID-19 has posed challenges for the construction industry, such as precise pandemic control, sustainable labor relations, and loss minimization. In response to these challenges, this study has developed a decision model that optimizes workforce allocation for projects to achieve sustainable workforce management, a tradeoff between pandemic prevention and work resumption. The priority of project resumption was evaluated using basic characteristics, the long- and short-term strategies, and the regional pandemic situation. The energy level of skilled workers was graded according to construction team size, skill level, and experience. Sustainable allocation principles and paths were explored to target four different types of work resumption plans. We used the cellular automaton (CA) technique to simulate the sustainable allocation model. We also analyzed the similarity function of energy levels and the time-cost function of allocation. The case study of the SGJ Construction demonstrates that this allocation model can accurately simulate work resumption and provide a sustainable allocation decisions and tools under pandemic. Also, it implies balanced interests and concerns between construction companies and the society for work resumption during COVID-19.
\end{abstract}

Keywords: skilled workers; work resumption; priority; energy similarity; cellular automaton

\section{Introduction}

In late 2019 and early 2020, the COVID-19 breakout pressed the pause button for work and life in China. The pandemic affected various industries including the construction industry, which has high requirements on project scheduling and cost control. To mitigate losses due to work suspension, construction companies paid attention to local disease control policies in project areas and planned for work resumption when possible.

However, when and how to resume projects is challenging for project management. It is known that construction companies often carry out several projects at the same time, which has been called project pool in this paper. The widespread pandemic has affected project pool in different locations and nearby labor recruitment centers. A sustainable work-resumption plan should consider both project characteristics and local pandemic situation when allocating resources.

The construction industry always lacks stock of skilled workers due to the gradual withdrawal of the older generation, unrefined vocational and technical education, and insufficient reserve of young skilled workers [1]. The pandemic makes the problem of workforce shortage worse because skilled workers are locked down and unable to move to the workplace. The construction industry is labor intensive, and this problem severely harms work resumption for construction companies. The post-pandemic recovery process requires the whole society to stabilize labor relations, support the efforts for business and production resumption, and maintain a balance between business development and worker rights [2]. 
The object of this paper is to develop a model to allocate skilled construction workers for during and post-pandemic work resumption. The model considers the situation of precise pandemic prevention and control, orderly work resumption, and legitimate protection of worker rights and interests. The following research questions listed below are those that construction companies must systematically analyze:

- The work resumption prioritization: that is, what projects should resume first and what can resume later?

- The work resumption scheduling: that is, how to return available and skilled workers to full employment?

- How to stabilize the labor relationship and improve the construction company's resumption simultaneously during the pandemic period.

A feasible way to answer these questions is to utilize the principle of temporal and spatial coordination to gradually achieve work resumption, give priority to the construction of key projects and those in regions with mild pandemic, and allocate existing skilled workers in an orderly manner whenever possible.

\section{Literature Review}

This paper follows two kinds of languages to aggregate the final collection of papers. One was English literature with the following subject headings in CNKI: "TS=(manpower* AND allocation * AND construction) or TS=(labor* AND allocation* AND construction) or $\mathrm{TS}=\left(\right.$ worker* ${ }^{*}$ AND allocation* AND construction $)$ or TS $=\left(\right.$ workforce* ${ }^{*}$ AND allocation* AND construction)" or "TS=(manpower* AND allocation* AND project) or TS=(labor* AND allocation* AND project) or TS=(worker* AND allocation* AND project) or TS $=$ (workforce ${ }^{*}$ AND allocation* AND project)" as search terms in WOS. The other was Chinese literature with "TS=(manpower* AND allocation* AND construction) or (worker* AND allocation* AND construction)" Or "TS=(manpower* AND allocation* AND project) or (worker* AND allocation* AND project)". There are a great deal of Chinese papers; thus, we only chose papers published within the last five years for relevance. Then, 39 English articles and 28 Chinese articles that were closely relevant to topic were selected and analyzed.

Research on the workforce allocation of the construction industry includes topics of single project and project pool.

The workforce allocation in single projects has been extensively discussed for a long time [3]. Many of them focus on construction factors such as cost, time, technique, etc., that affect project staffing assignments. In the classical research by K. R. Persad et al., the working time of a single construction project was predicted by establishing a regression analysis model, and it was concluded that the project cost and project category are the key factors for the prediction of the manpower requirements of the project to realize optimal personnel allocation [4]. S. W. Whang et al. identified and ranked the critical design-management factors for design teams to understand how appropriate designer allocation can positively affect project performance and profit [5]. Zhang Xizheng, Luo Wen, and Cai Yueyue proposed a multi-objective task allocation model with minimum project duration, lowest cost, and minimum number of contractors [6]. W. J. Yang and Y. S. Kim presented a method for improving the accuracy of construction-site engineer allocation by site technological risks, according to data analysis from 31 case projects [7]. The other articles pay more attention to workforce elements, such as society, cognitive behavior, career development, etc., that play a powerful role in allocative efficiency. For example, Ballesteros-Pérez et al. proposed that project managers should focus on social interaction when screening workers from a given repository to achieve the highest work efficiency [8]. P. C. Liao et al. used SEM to identify the cognitive structure of steel workers and elevator workers and found that there were significant differences between them, indicating that in terms of manpower allocation, more attention should be paid to the team leader or foreman of mechanical workers and correspondingly more self-supporting capability for rebar crews [9]. B. Shahbazi et al. used the balance construction corporate objectives, such as maximizing productivity and objectives of construction workers' career 
development needs in the future, based on the use of Pareto Optimality and Pareto Curve, to create a double-target model so as to build a new allocation dimension of construction workers [10].

At present, the research on the perspective of workforce allocation in project pool is popular. Some scholars prefer to take multiple projects as the core and allocate qualified construction workers for them. Project priority has been defined to more effective workforce allocation in a multi-project environment. Mats Engwall et al. believed that multi-projects running in parallel are interdependent, and the priority definition of project pool needs to consider many factors dynamically, and the workforce allocation among projects could reconstruct organizational structure [11]. Masataka et al. used a project optimization system to find the project portfolio with the largest total revenue and the optimal manpower allocation method in such a portfolio [12]. Chen Junjie et al. established a multi-project evaluation system based on a multi-level fuzzy comprehensive evaluation method [13]. El-Abbasy et al. presented an optimization model for multiple construction projects to solve the problems of prioritizing projects under resource-conflict conditions, allocating limited workforce, and optimizing all the projects' multiple objectives under certain funding limits [14]. Some scholars focus on the form and characteristics of labor force to achieve efficient allocation in project pool. Zhong Yong et al. discussed the causal relationship between resource availability and work operability and found significant differences between labor and other resource allocation via a system dynamics model in multiple projects [15]. Y. H. Hou et al. targeted project managers' optimization for multi-project with period-equilibrium and minimization of total labor cost and built a two-stage optimization model based on a linear programming algorithm and the greedy algorithm to demonstrate the effectiveness of optimal allocation [16]. L. Florez established a system for efficient crew allocation in the masonry industry formulated as a mixed-integer program and showed the substantial impact on reducing the completion time to build the walls, maximizing the utilization of masons, and outlining opportunities for concurrent work [17]. Yunjeong Mo et al. created a machine-learning model that read labor request texts and predicted priority and then automatically assigned workforce through the technique of natural language processing (NLP) [18]. Some studies have extended personnel allocation in project pool to worker teams. C. Koch and J. Marton described a Scandinavian model in which construction teams with a number of multi-skilled workers were extensively cultivated and used in the construction sites [19]. H. R. Thomas and M. J. Horman. cited fundamental principles related to labor performance of site construction management and discussed the strategies to improve construction team productivity [20]. M. Walter and J. Zimmermann realized that large project teams come along with productivity losses due to increased coordination effort and social loafing between projects and thus formulated a mixed-integer linear program that minimized average project team size [21]. L. I. Wenhua, L. Peng, and D. Zhang found that the heterogeneity of team leaders made a difference in construction team performance, and their competency was affected by their educational background and service types [22]. Y. Anoshkina and F. Meisel analyzed the problem of composing worker teams and routing and scheduling these teams under goals-expressing service-, fairness-, and cost-objectives in different locations by an optimization model and provided a bi-level decomposition scheme [23]. In addition, allocation of multi-skilled workers played a more and more important role among multiple projects. Drezet and Billaut comprehensively considered the role of multi-capability in the allocation of human resources to a project, constructed an integer-programing model under this constraint, and used the greedy algorithm and TABU search method to find the optimal solution [24]. A. Nasirian et al. paid great attention to multiskilling to introduce configuration, strategy, collateral effects, context, and mainstream research on the multiskilling in the construction industry and in the mean-time to the dynamic reallocation of multi-skilled labors in prefabricated construction with multitasking $[25,26]$. M. Sarihi et al. proposed a simulation framework for assigning multi-skilled workforces across multiple projects on the basis of 
workers' competency status toward minimizing resource and costs and maximizing social sustainability [27].

From the above, some things could be found. First of all, excavation and evaluation of the project and labor force is the foundation of effective allocation among construction projects. Additionally, many studies mentioned the priorities and ranking in project pool. Then, the development of allocation model is an important means and method to deal with management performance between them. However, the following problems existed in previous studies: (1) most construction project pools utilized multi-objective planning to consider the effective allocation of workforce and did not consider the allocation of labors in severe disturbance (e.g., suffering a pandemic); (2) the allocation models were mainly focused on the benefits of cost and schedule, and insufficient attention was paid to the long-term strategy and social responsibility of construction companies. Therefore, this paper emphasizes the balance between pandemic prevention and work resumption. Both strategic-level objectives and sustainable employment responsibilities are comprehensively considered to provide systematic management ideas for the orderly work resumption of skilled workers in project pools of construction companies.

\section{Indicator System Design}

The assessment model considers two principles: (i) prioritizing work resumption in regions of mild pandemic situations and postponing that in regions of severe pandemic situations; and (ii) matching project needs with worker skills measured by the energy-level metrics. The first step is to determine the priority of each project in the construction company's project pool (U) and the energy level of the skilled workers and then to consider the impact of the pandemic. Among them, energy level has been defined as the amount of energy and the level of ability of skilled workers or construction teams to complete construction tasks. The amount of energy indicates the size and quantity, while the level of ability emphasizes experience and quality.

\subsection{Prioritization of the Projects in a Project Pool during a Pandemic \\ 3.1.1. Indicators for Project Prioritization}

In this paper, evaluation indicators of the project priority were determined by comprehensively using the methods of literature induction and expert interview. From the literature review, many studies mentioned the priorities and ranking in project pool (details in Section 2). All the basic assessment indicators were collected, and the main factors, such as construction area, contract amount, profit, duration, total cost, financing cost, quality, technical, and strategies, were selected in the perspective of a construction company. We took into consideration that the priority of projects is influenced by different dimensions, which have been divided into the operational level and strategic level. The operational level should consider not only the scale and profit of the project but also the specific requirements of the project, such as its duration, quality, and technology. For the strategic level, it is necessary to respectively consider the long- and short-term needs. Then five construction specialists, as detailed in Table 1, were initially invited to find out the suitable and available indicators as well as to supplement, correct, and improve them. According to their experience, the specialists then discussed and presented the final indictors and the evaluation criteria. As a result, remaining contract amount (A1), profit per unit of time (A2), remaining duration (A3), quality (A4), level of technical complexity (A5), impact of the project on short-term enterprise strategies (A6), and impact of the project on long-term enterprise strategies (A7) were confirmed. The average level of each indictor was adjusted according to the overall situation of the construction project pool, and a five-level scoring method was referred. The evaluation indictors and criteria are presented in Table 2. 
Table 1. Introduction to specialists.

\begin{tabular}{cccccc}
\hline Work Unit & Title & Number & Age (Avg.) & Work Experience (Avg.) & Method \\
\hline Universities & Professor & 2 & 40 & 8 & Face-to-face \\
Construction companies & Manager & 3 & 45 & 12 & Online (WeChat) \\
\hline
\end{tabular}

Table 2. The basic indicators and evaluation criteria for priorities of projects in a project pool.

\begin{tabular}{|c|c|c|c|c|c|}
\hline Indicator System & $0.8-1$ & $0.6-0.8$ & $\begin{array}{c}\text { Evaluation Criteria } \\
0.4-0.6\end{array}$ & $0.2-0.4$ & $0-0.2$ \\
\hline & Very large & Large & Average & Small & Very small \\
\hline $\begin{array}{c}\text { Remaining contract } \\
\text { amount } \\
\text { A1 }\end{array}$ & $\begin{array}{l}\text { More than } 50 \% \text { of the } \\
\text { total remaining } \\
\text { amount of the annual } \\
\text { contract of the } \\
\text { enterprise }\end{array}$ & $\begin{array}{l}30-50 \% \text { of the total } \\
\text { remaining amount of } \\
\text { the annual contract of } \\
\text { the enterprise }\end{array}$ & $\begin{array}{l}10-30 \% \text { of the total } \\
\text { remaining amount of } \\
\text { the annual contract } \\
\text { of the enterprise }\end{array}$ & $\begin{array}{l}5-10 \% \text { of the total } \\
\text { remaining amount of } \\
\text { the annual contract of } \\
\text { the enterprise }\end{array}$ & $\begin{array}{l}\text { Less than } 5 \% \text { of the } \\
\text { total remaining } \\
\text { amount of the annual } \\
\text { contract of the } \\
\text { enterprise }\end{array}$ \\
\hline \multirow[b]{2}{*}{$\begin{array}{l}\text { Profit per unit of time } \\
\text { A2 }\end{array}$} & Very large & Large & Average & Small & Very small \\
\hline & $\begin{array}{c}\text { More than } 50 \% \text { above } \\
\text { the average } \\
\text { enterprise level }\end{array}$ & $\begin{array}{c}10-50 \% \text { above the } \\
\text { average enterprise } \\
\text { level }\end{array}$ & $\begin{array}{c}\text { Within } 10 \% \text { of the } \\
\text { average enterprise } \\
\text { level }\end{array}$ & $\begin{array}{l}\text { 10-50\% below the } \\
\text { average enterprise } \\
\text { level }\end{array}$ & $\begin{array}{c}\text { More than } 50 \% \text { below } \\
\text { the average } \\
\text { enterprise level }\end{array}$ \\
\hline \multirow[b]{2}{*}{$\begin{array}{l}\text { Remaining duration } \\
\text { A3 }\end{array}$} & Very high & High & Normal & Low & Very low \\
\hline & $\begin{array}{l}\text { More than } 20 \% \\
\text { longer than the } \\
\text { normal duration of } \\
\text { similar projects }\end{array}$ & $\begin{array}{l}10-20 \% \text { longer than } \\
\text { the normal duration } \\
\text { of similar projects }\end{array}$ & $\begin{array}{l}\text { Within } 10 \% \text { of the } \\
\text { normal duration of } \\
\text { similar projects }\end{array}$ & $\begin{array}{l}10-20 \% \text { shorter than } \\
\text { the normal duration } \\
\text { of similar projects }\end{array}$ & $\begin{array}{l}\text { More than } 20 \% \\
\text { shorter than the } \\
\text { normal duration of } \\
\text { similar projects }\end{array}$ \\
\hline \multirow[b]{4}{*}{$\begin{array}{c}\text { Level of technical } \\
\text { complexity } \\
\text { A5 }\end{array}$} & Very high & High & Normal & Low & Very low \\
\hline & $\begin{array}{l}\text { Exceeding the } \\
\text { enterprise quality } \\
\text { standards and } \\
\text { proposing to apply } \\
\text { for national awards }\end{array}$ & $\begin{array}{l}\text { Exceeding the } \\
\text { enterprise quality } \\
\text { standards and } \\
\text { proposing to apply } \\
\text { for awards in the } \\
\text { administration region }\end{array}$ & $\begin{array}{l}\text { Meeting corporate } \\
\text { quality standards }\end{array}$ & $\begin{array}{l}\text { Lower than the } \\
\text { quality standards of } \\
\text { the enterprise and } \\
\text { higher than national } \\
\text { and local standards }\end{array}$ & $\begin{array}{l}\text { Lower than local } \\
\text { standards, higher } \\
\text { than mandatory } \\
\text { national standards }\end{array}$ \\
\hline & Very high & High & Average & Low & Very low \\
\hline & $\begin{array}{l}\text { The technical } \\
\text { difficulty factor is } \\
\text { much higher than the } \\
\text { average for similar } \\
\text { projects }\end{array}$ & $\begin{array}{l}\text { The technical } \\
\text { difficulty factor is } \\
\text { slightly higher than } \\
\text { the average for } \\
\text { similar projects }\end{array}$ & $\begin{array}{l}\text { The technical } \\
\text { difficulty factor is at } \\
\text { the average level of } \\
\text { similar projects }\end{array}$ & $\begin{array}{l}\text { The technical } \\
\text { difficulty factor is } \\
\text { slightly lower than } \\
\text { the average for } \\
\text { similar project }\end{array}$ & $\begin{array}{l}\text { The technical } \\
\text { difficulty factor is } \\
\text { well below the } \\
\text { average for similar } \\
\text { projects }\end{array}$ \\
\hline \multirow[b]{2}{*}{$\begin{array}{l}\text { Impact of the project } \\
\text { on short-term } \\
\text { enterprise strategies } \\
\text { A6 }\end{array}$} & Significant & Large & General & Small & Very small \\
\hline & $\begin{array}{l}\text { Project success or } \\
\text { failure is a sufficient } \\
\text { condition for the } \\
\text { achievement of } \\
\text { short-term strategies }\end{array}$ & $\begin{array}{l}\text { Project success or } \\
\text { failure is a necessary } \\
\text { condition for the } \\
\text { achievement of } \\
\text { short-term strategies }\end{array}$ & $\begin{array}{c}\text { Project success or } \\
\text { failure is a condition } \\
\text { for the achievement } \\
\text { of short-term } \\
\text { strategies }\end{array}$ & $\begin{array}{l}\text { Project success or } \\
\text { failure has less } \\
\text { impact on short-term } \\
\text { strategies }\end{array}$ & $\begin{array}{l}\text { Project success or } \\
\text { failure has no impact } \\
\text { on short-term } \\
\text { strategies }\end{array}$ \\
\hline \multirow[b]{2}{*}{$\begin{array}{l}\text { Impact of the project } \\
\text { on long-term } \\
\text { enterprise strategies } \\
\text { A7 }\end{array}$} & Significant & Large & General & Small & Very small \\
\hline & $\begin{array}{l}\text { Project success or } \\
\text { failure is the only } \\
\text { basis for adjusting } \\
\text { long-term strategies }\end{array}$ & $\begin{array}{l}\text { Project success or } \\
\text { failure is an } \\
\text { important criterion } \\
\text { for adjusting } \\
\text { long-term strategies }\end{array}$ & $\begin{array}{l}\text { Project success or } \\
\text { failure is one of the } \\
\text { bases for adjusting } \\
\text { long-term strategies }\end{array}$ & $\begin{array}{l}\text { Project success or } \\
\text { failure has less } \\
\text { impact on short-term } \\
\text { strategies }\end{array}$ & $\begin{array}{l}\text { Project success or } \\
\text { failure has no impact } \\
\text { on long-term } \\
\text { strategies }\end{array}$ \\
\hline
\end{tabular}

The average level of the contract amount can be adjusted according to the overall situation of the project pool (); replacing the contract amount with the remaining contract amount is favorable for transferring quality resources from projects nearing completion to new or longer projects during the construction process. Replacing the total construction period with the remaining construction period is conducive for the system to grasp the current situation of the delay or advance of the construction period. Enterprise quality standards are generally higher than local standards and mandatory national standards.

\subsubsection{Pandemic Impact Indicators for Project Priorities}

In a pandemic, the contract performance, cost, and schedule of each project will be affected to a different degree. Therefore, in addition to the basic evaluation indicators, it is also necessary to consider the pandemic indicators of the project location. The time point 
of 29 February 2020 was selected. According to the data released by the China National Health and Wellness Commission, the BAIDU Pandemic Map provides information on the pandemic situation of each area, and the pandemic level of each province (municipalities directly under the authority of the central government and autonomous regions) is determined by the cumulative number of confirmed cases [28]. For details, see Figure 1.

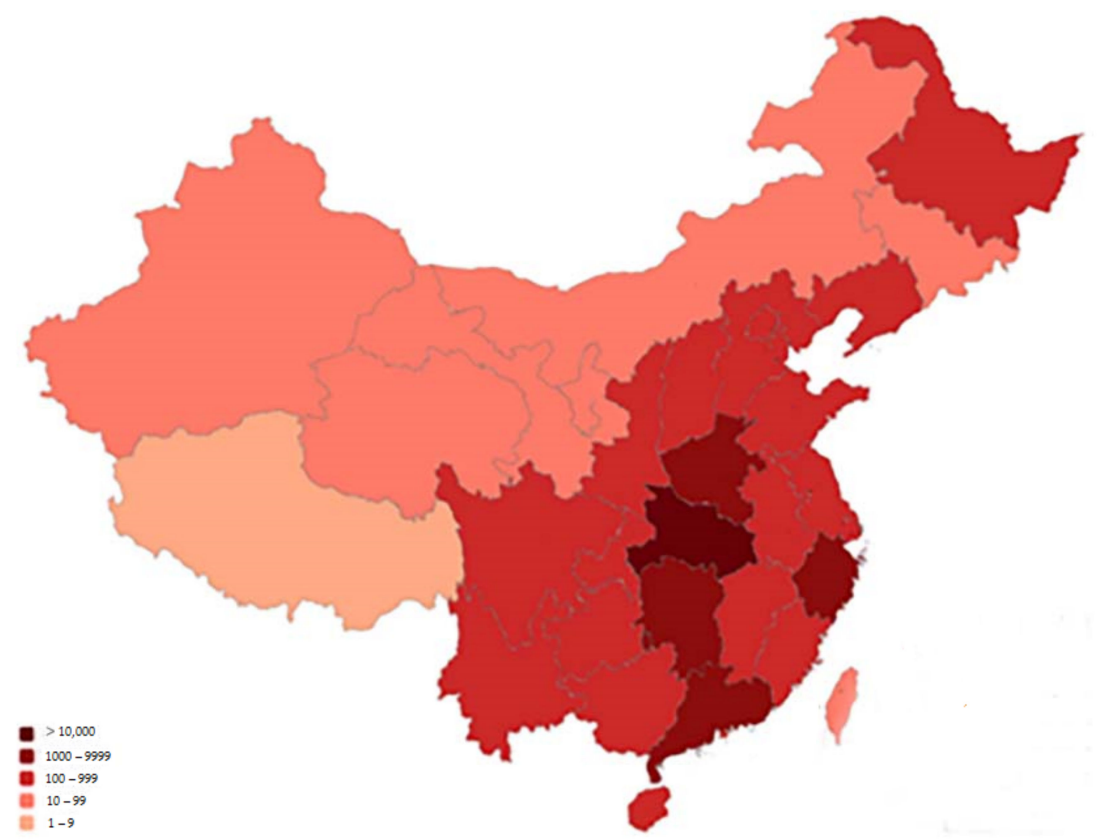

Figure 1. A map of the nationwide COVID-19 pandemic in China.

At the request of the State Council of China, the risk was calculated based on the cumulative number of confirmed cases, the proportion of local cases, the number of clustered pandemic cases, and the newly confirmed cases in consecutive days in each county (district) under the jurisdiction of the province (municipality directly under the authority of the central government or autonomous region) as the unit, and the pandemic situation in each region was regularly announced [29]. The classification of most provinces was collected, and the severity of the pandemic was categorized as high risk, relatively high risk, medium risk, relatively low risk, or low risk. The pandemic impact on the project priority was based on the condition of the pandemic in the project location; $C_{i}$ indicates the degree of the pandemic impact on the priority of project $i$. The evaluation criteria are presented in Table 3. Among them, the pandemic impact indicators take into account the current situation of the pandemic in the province (municipality directly under the authority of the central government or autonomous region) where the project is located as well as the pandemic differences among different counties (districts) in the same province (municipality directly under the authority of the central government or autonomous region). The calculation formula is as follows:

$$
C_{i}=C_{i} \text { Prov. } \times C_{i} \text { CTY. } .\left(C_{i} \in[0.1 \times 0.1,0.9 \times 0.9]\right)
$$

\subsubsection{Assessment Models for Project Priorities in a Pandemic}

The most important characteristics of construction projects are their uniqueness, environmental impact, heterogeneity, and complexity. Due to individual characteristics and external demands, the evaluation indexes of projects in a project pool exhibit differences. To characterize these differences more objectively, the entropy-weighting method is used in this paper to determine the weights of project priority indicators. Different from other evaluation methods, such as analytic hierarchy process and fuzzy comprehensive evaluation method, the priority of a project is the relative priority obtained by comparing with 
others in the project pool, which is consistent with the theory of the entropy-weighting method. For the theoretical basis and implementation steps, readers can refer to the related literature $[30,31]$.

Table 3. Pandemic impact indicators and evaluation criteria of projects.

\begin{tabular}{|c|c|c|c|c|c|}
\hline \multirow{2}{*}{ Indicator System } & \multicolumn{5}{|c|}{ Evaluation Criteria } \\
\hline & 0.9 & 0.7 & 0.5 & 0.3 & 0.1 \\
\hline \multirow[b]{2}{*}{$\begin{array}{l}\text { Pandemic levels of the } \\
\text { province (municipality } \\
\text { directly under the } \\
\text { authority of the central } \\
\text { government or } \\
\text { autonomous region) } \\
C_{i} \text { Prov. }\end{array}$} & High risk & Relatively high risk & Medium risk & Relatively low risk & Low risk \\
\hline & $\begin{array}{l}\text { Cumulative number } \\
\text { of confirmed cases } \\
\geq 10,000\end{array}$ & $\begin{array}{l}\text { Cumulative number } \\
\text { of confirmed cases } \\
\text { between 1000-9999 }\end{array}$ & $\begin{array}{l}\text { Cumulative number } \\
\text { of confirmed cases } \\
\text { between 100-999 }\end{array}$ & $\begin{array}{l}\text { Cumulative number } \\
\text { of confirmed cases } \\
\text { between 10-99 }\end{array}$ & $\begin{array}{l}\text { Cumulative number } \\
\text { of confirmed cases } \\
\text { between 1-9 }\end{array}$ \\
\hline \multirow[b]{2}{*}{$\begin{array}{l}\text { Local pandemic level } \\
\qquad C_{i} C T Y\end{array}$} & High risk & Relatively high risk & Medium risk & Relatively low risk & Low risk \\
\hline & \multicolumn{5}{|c|}{$\begin{array}{c}\text { The pandemic risk level of each county or city (district) published during the reporting period shall prevail (adjusted } \\
\text { every } 14 \text { days) }\end{array}$} \\
\hline
\end{tabular}

During the process, the assessment value of each project indicator is determined jointly by project and enterprise managers with rich technical experience and management experience. In view of their different understandings of the operational- and strategic-level indicators, the operational-level indicators rely more on the scores of project-level managers, while the strategic-level indicators are more dependent on the scores of enterprise-level managers. Let the number of project-level managers in a survey of project $i$ be $\overline{\mathrm{u}}$, let the number of management personnel at the enterprise level be $\bar{v}$, and let the scores of the evaluation indexes of project $i$ by project- and enterprise-level experts be $x_{i j}{ }^{u}$ and $x_{i j}{ }^{v}$, respectively. Then, the average comprehensive score $X_{i j}$ of indicator $j$ for item $i$ is

$$
X_{i j}=\alpha_{\mathbf{u}} \sum_{\mathbf{u}=1}^{\overline{\mathrm{u}}} x_{i j}{ }^{u} / \overline{\mathrm{u}}+\alpha_{\mathrm{v}} \sum_{\mathbf{v}=1}^{\bar{v}} x_{i j}{ }^{j} / \bar{v},
$$

where $\alpha_{\mathrm{u}}$ is the weight of expert ratings at the project level, $\alpha_{\mathrm{v}}$ is the weight of expert ratings at the enterprise level, and $\alpha_{\mathrm{u}}+\alpha_{\mathrm{v}}=1$. When calculating the comprehensive score of operational-level indicators (A1, A2, A3, A4, A5), $\alpha_{\mathrm{u}}>\alpha_{\mathrm{v}}$; when calculating the comprehensive score of enterprise-level indicators (A6, A7), $\alpha_{\mathrm{u}}<\alpha_{\mathrm{v}}$.

The comprehensive score $X_{i j}$ of each sub-item is substituted into the initial decision matrix, and the weight $W_{j}$ of each index is obtained by the entropy-weight method. Then, it is substituted into the priority evaluation model together with the weights to obtain the comprehensive score of the basic priority of each project. In other words, the foundation priority scores for project $i$ are:

$$
I_{i}=W_{1} X_{i 1}+W_{2} X_{i 2}+W_{3} X_{i 3}+W_{4} X_{i 4}+W_{5} X_{i 5}+W_{6} X_{i 6}+W_{7} X_{i 7}
$$

Because the impact of a pandemic is comprehensive, the pandemic impact indicators act on the overall priority score of each project. Moreover, the more serious the pandemic, the lower the expectation of the projects to resume production and the lower their priority score. In other words, the revised priority score for project $i$ in a pandemic is.

$$
I_{i}^{\prime}=I_{i} /\left(e^{C_{i}}\right)
$$

The priorities of each project of project pool $U$ can be ranked and numbered according to their basic and modified scores:

$$
\left\{P_{a}\right\}=\left\{\max _{i} \rightarrow \min I_{i}\right\}
$$




$$
\left\{\left(P_{a}\right)^{\prime}\right\}=\left\{\max _{i}^{\prime} \rightarrow \min _{i}^{\prime}\right\},
$$

where $1 \leq a \leq n(a \in N)$, where $n$ is the number of projects in the pool of a construction company, $P_{a}$ represents the project priority in a general state, and $\left(P_{a}\right)^{\prime}$ represents the project priority when taking into account the impact of a pandemic.

\subsection{Energy Level Assessment of Skilled Workers in a Project Pool}

The term energy level was first derived from physics and later introduced into human resource management, thereby forming the principle of energy-level proportionality. It was used to emphasize that workforce should be assigned work responsibilities and work content according to maximize their abilities and achieve management objectives [16]. For a project pool of a construction company, each project has different project characteristics and requires different types of workers. Most skilled workers currently arrange and settle work tasks with the construction team as a unit, which considers that the contract signed by an individual is actually performed by the construction team in China. Therefore, a construction team is considered a basic unit when measuring the energy level of skilled workers, which is the skill set of the group [23]. By definition of energy level, assessment model of construction workforce has referred not only to size of construction teams, but also to the richness of their construction experience and quality. After literature review and discussing with specialists, the size of the construction team would be expressed by the number of team members [20]; the experience is mainly examined with the average working years of construction teams and the number of similar projects completed by the team [19]; the skill level would describe quality and mainly be measured by the proportion of senior skilled workers in the construction team.

The energy-level assessment indicator system of a construction team in a project pool is presented in Figure 2.

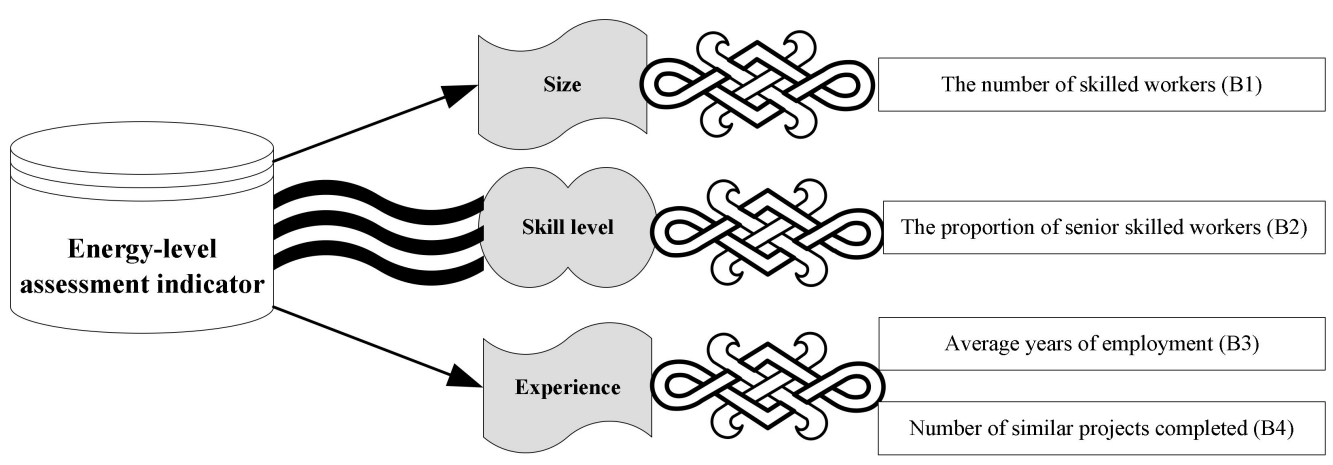

Figure 2. Energy-level assessment indicator system of a construction team in a project pool.

Considering that home building comprises the largest proportion of skilled workers in the construction industry, only housing construction is considered as an example in this paper to study the energy levels of workforce in the project pool. According to China's Occupational Classification Dictionary and the Catalogue of Occupational Skills Appraisal Standard Work Types issued by the Ministry of Housing and Construction, the main technical work types in housing construction projects include carpentry, plasterers, masonry workers, reinforcement workers, erectors, plumbers, mounters, earthwork machinery operators, vertical transport machinery operators, etc., which are expressed as $G_{-} b(b \in[1, m])$, where $m$ is the number of technical jobs in the project pool [32]. 
According to the energy-level assessment indicator of the construction team, the configuration of the construction team of type $G_{b}$ of project $P_{a}$ can be expressed as $T_{b a}$ :

$$
T_{b a}=\left[\begin{array}{c}
B_{1}^{b a} \\
B_{2}^{b a} \\
B_{3}^{b a} \\
B_{4}^{b a}
\end{array}\right] \text { or } T_{b a}=\left[\begin{array}{llll}
B_{1}^{b a} & B_{2}^{b a} & B_{3}^{b a} & B_{4}^{b a}
\end{array}\right]
$$

- $B_{1}^{b a} \in \mathrm{N}$

- $\quad B_{2}^{b a}$ - the level of skilled workers recognized by the state shall prevail for the senior skilled workers; if there is no relevant national certification, the comprehensive evaluation of the enterprise shall prevail;

- $\quad B_{3}^{b a}$-the average year of the construction team after removing the minimum and maximum;

- $\quad B_{4}^{b a}$-similar projects involving more than $50 \%$ of the construction team members shall prevail, and the participants must include the team leader [22].

\section{Allocation Model Development}

To focus on work resumption, it is assumed that the initially allotted skilled workers in a project pool before a pandemic are qualified, i.e., the energy level of the construction team well matches the needs of the project. The initial allocation matrix is shown in Table 4.

Table 4. The initial allocation matrix of construction teams before (without) a pandemic in a project pool.

\begin{tabular}{ccccccc}
\hline \multirow{2}{*}{ Type of Work } & \multicolumn{5}{c}{ Project Prioritization (from Highest to Lowest) } \\
\cline { 2 - 6 } & $\boldsymbol{P 1}$ & $\boldsymbol{P 2}$ & $\ldots$ & $\boldsymbol{P a}$ & $\ldots$ & $\boldsymbol{P n}$ \\
\hline$G_{1}$ & $T_{11}$ & $T_{12}$ & $\ldots$ & $T_{1 a}$ & $\ldots$ & $T_{1 n}$ \\
$G_{2}$ & $T_{21}$ & $T_{22}$ & $\ldots$ & $T_{2 a}$ & $\ldots$ & $T_{2 n}$ \\
$\ldots$ & $\ldots$ & $\ldots$ & $\ldots$ & $\ldots$ & $\ldots$ & $\ldots$ \\
$G_{b}$ & $T_{b 1}$ & $T_{b 2}$ & $\ldots$ & $T_{b a}$ & $\ldots$ & $T_{b n}$ \\
$\ldots$ & $\ldots$ & $\ldots$ & $\ldots$ & $\ldots$ & $\ldots$ & $\ldots$ \\
$G_{m}$ & $T_{m 1}$ & $T_{m 2}$ & $\ldots$ & $T_{m a}$ & $\ldots$ & $T_{m n}$ \\
\hline
\end{tabular}

\subsection{Basic Steps of Sustainable Allocation for Work Resumption in a Pandemic}

In a pandemic, the top priority is pandemic prevention, and the priority of projects change due to the consideration of the pandemic. The work resumption or recruitment of construction teams is also controlled by the areas from which labor services are exported and must occur in areas where they are allowed to be released. Therefore, the system configuration of a construction team in project pool $U$ should take into account the pandemic situation at the locations of the project and skilled workers. A construction company is required to resume work in their project pool according to the two basic principles outlined in Section 3. The basic sustainable allocation steps are as follows.

Step 1: Check the work resumption of each project and its construction team. When a pandemic situation stabilizes and improves, the construction teams of some projects will resume work or confirm their intention and time frame for resuming work via communication tools. During the investigation, as long as the team leader of the construction team and the main senior technician workers confirm that they are returning to the original site, the construction team is considered to be unchanged. Other general workers are allowed to be dynamically adjusted according to the pandemic situation to effectively avoid the interruption of the whole construction team resuming work due to the loss of individual non-critical workers. Moreover, the skilled workers in the construction team generally come from the same geographical location or family, for which the pandemic situation is similar; thus, the district location conditions for the work resumption of the construction team can only be constructed by the team leader. 
Based on various circumstances, there are four types of projects and work resumption of their construction teams, as detailed in Table 5; $U=U^{I}+U^{I I}+U^{I I I}+U^{I V}$.

Table 5. The analysis of the work resumption for a project and its construction team in a pandemic.

\begin{tabular}{|c|c|c|c|c|c|c|}
\hline Situation & $\begin{array}{l}\text { Resumption of } \\
\text { Projects }\end{array}$ & $\begin{array}{c}\text { Resumption of } \\
\text { Construction Teams }\end{array}$ & $\begin{array}{l}\text { Total } \\
\text { Number }\end{array}$ & Project Set & $\begin{array}{l}\text { Construction } \\
\text { Team Set }\end{array}$ & Analysis \\
\hline I & $\begin{array}{l}\text { Conditions are in } \\
\text { place to resume } \\
\text { projects }\end{array}$ & $\begin{array}{l}\text { Conditions are in place to } \\
\text { resume } \\
\text { construction teams }\end{array}$ & $n^{I}$ & $U^{I}$ & $G^{I}$ & $\begin{array}{c}\text { Direct work resumption } \\
\text { without } \\
\text { reallocation }\end{array}$ \\
\hline II & $\begin{array}{l}\text { Conditions are in } \\
\text { place to resume } \\
\text { projects }\end{array}$ & $\begin{array}{l}\text { Failure to meet } \\
\text { conditions for the } \\
\text { resumption of } \\
\text { construction teams }\end{array}$ & $n^{I I}$ & $U^{I I}$ & $G^{I I}$ & The main allocations \\
\hline III & $\begin{array}{l}\text { Failure to meet } \\
\text { conditions for the } \\
\text { resumption of } \\
\text { projects }\end{array}$ & $\begin{array}{l}\text { Conditions are in place to } \\
\text { resume } \\
\text { construction teams }\end{array}$ & $n^{I I I}$ & $U^{I I I}$ & $G^{I I I}$ & $\begin{array}{l}\text { The construction team is } \\
\text { allocated into II in time }\end{array}$ \\
\hline IV & $\begin{array}{l}\text { Failure to meet } \\
\text { conditions for the } \\
\text { resumption of } \\
\text { projects }\end{array}$ & $\begin{array}{l}\text { Failure to meet } \\
\text { conditions for the } \\
\text { resumption of } \\
\text { construction teams }\end{array}$ & $n^{I V}$ & $U^{I V}$ & $G^{I V}$ & $\begin{array}{l}\text { Make pre-arrangements } \\
\text { for the work resumption } \\
\text { of subsequent projects } \\
\text { and waiting workers }\end{array}$ \\
\hline
\end{tabular}

Considering situations II, III, and IV, the two starting points are as follows: conditions are in place to resume projects and failure to meet conditions for the resumption of projects. The lost construction teams for the projects that meet the conditions for resumption $\left(U^{I I}\right)$ are replenished on the basis of the project priority of the general state $P_{a}$; a qualified construction team is prepared for the projects that fail to meet the conditions for resumption $\left(U^{I I I}+U^{I V}\right)$ on the basis of the project priority under the impact of the pandemic $\left(P_{a}\right)^{\prime}$. During the survey, the construction teams that were committed to resuming work during the pandemic waiting period are recorded, as is the estimated waiting time for work resumption (subject to documents issued by the local government, the transportation time for returning to work, etc.). For the construction teams that have met the conditions for work resumption but have been stranded because the project does not meet the conditions for work resumption, the waiting time is expressed as a negative number. The construction teams that have confirmed to have not resumed work during the pandemic waiting period are highlighted and then listed as lost construction teams. The energy level of each project corresponding to the lost construction team has been determined.

Step 2: Search for construction teams with similar energy levels for situation II. For $U^{I I}$, the project priority ranking is $\left\{P_{1}^{I I}, P_{2}^{I I}, \ldots \ldots, P_{a}^{I I}, \ldots \ldots, P_{n}^{I I}\right\}$. Accordingly, search for construction teams with similar energy levels from highest to lowest in $G^{I I I}$. The finite set of the results is $G_{k}^{I I I}$, where $k$ is the project number in $U^{I I I}$. Let $\operatorname{Sim}\left(T_{b a}^{I I}, T_{b k}^{I I I}\right)$ be the energy similarity function, the value of which is $s(k)$. The corresponding projects of construction teams with similar energy levels in $G^{I I I}$ are:

$$
\{k \mid \max \{s(k)\}\}, K^{*}=\{k \mid \max \{s(k)\}\}
$$

where $1<\mathrm{a} \leq n^{I I}$ and $1<k \leq n^{I I I}$. When $n^{I I} \leq n^{I I I}$, considering the social responsibility to sustain labor relations and the scarcity of skilled workers during the pandemic period, select construction teams with similar energy levels in $G^{I I I}$ for the projects in $U^{I I}$ to the greatest possible extent, and the remaining construction teams in $G^{I I I}$ are described as $\triangle k \geq 0$. When $n^{I I}>n^{I I I}$, if $\triangle k=0$, the shortfall is to be compensated for by the external market. 
Considering the moment before the pandemic as $t_{0}$, the corresponding construction teams of projects in $U^{I I}$ according to the project priority are as follows:

\begin{tabular}{|llllll|}
\hline$T_{b 1}$ & $T_{b 2}$ & $\ldots \ldots$ & $T_{b a}$ & $\ldots \ldots$ & $T_{b n^{I I}}$ \\
\hline
\end{tabular}

Considering the moment of the pandemic waiting period as $t_{1}$, the construction team $K^{*}$ with the greatest similarity in energy level in $G^{I I}$ is configured to match $U^{I I}$ by the ranking $\left\{P_{1}^{I I}, P_{2}^{I I}, \ldots \ldots, P_{a}^{I I}, \ldots \ldots, P_{n}^{I I}\right\}$, which fails to meet the conditions for the resumption of construction teams; the insufficient team from $G^{I I}$ is considered to be obtained from the labor market and is recorded as $T_{Z}$. At this point, the construction team state $r_{1}$ can be expressed as follows:

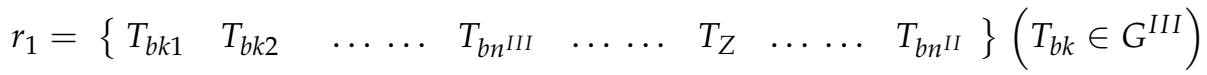

Step 3: Prepare construction teams with similar energy levels for situations III and IV. For $U^{I I I}+U^{I V}$, the priority of projects in a pandemic is $\left\{\left(P_{1}^{I I I+I V}\right)^{\prime},\left(P_{2}^{I I I+I V}\right)^{\prime}, \ldots \ldots,\left(P_{a}^{I I I+I V}\right)^{\prime}, \ldots \ldots,\left(P_{n}^{I I I+I V}\right)^{\prime}\right\}$. The construction team $K^{*}$ with the greatest similarity in energy level in $\left(G^{I I}+\overline{G_{k}^{I I I}}+G^{I V}\right)$ is allocated to $U^{I I I}+U^{I V}$ by the priority of projects that lost construction teams during the pandemic (adding to II is also considered a loss); the shortfall is considered to be compensated for by the labor market and is recorded as $T_{\mathrm{Z}}$.

At $t_{0}$, the corresponding construction teams of projects in $\left(U^{I I I}+U^{I V}\right)$ during a pandemic according to the project priority are as follows:

\begin{tabular}{|c|c|}
\hline$\left(T_{b 1}\right)^{\prime}$ & $\left(T_{b 2}\right)^{\prime}$ \\
\hline
\end{tabular}

At $t_{1}$, if $\left(T_{b a}\right)^{\prime}$ is lost, the construction teamwith the greatest similarity in energy level in $\left(G^{I I}+\overline{G_{k}^{I I}}+G^{I V}\right)$ is prepared in advance to $U^{I I I}+U^{I V}$ by the ranking $\left\{\left(P_{1}^{I I+I V}\right)^{\prime},\left(P_{2}^{I I I+I V}\right)^{\prime}, \ldots \ldots,\left(P_{a}^{I I I+I V}\right)^{\prime}, \ldots \ldots,\left(P_{n}^{I I I+I V}\right)^{\prime}\right\}$, which fails to meet the coitions for the resumption of projects. At this point, the construction team state $r_{1}$ can be expressed as follows (Figure 3):

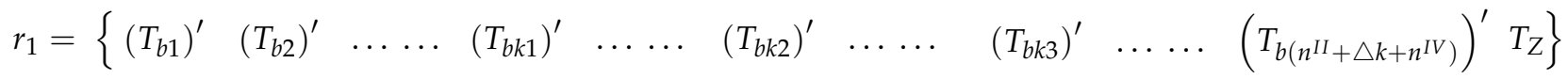

4.2. Model Establishment and Sustainable Allocation Parametric Analysis Based on Cellular Automaton

4.2.1. Establishment of the Allocation Model for Work Resumption Based on Cellular Automaton

Cellular automaton (CA) originated from von Neumann's simulation of the selfreplicating behavior of organisms and is defined as a dynamic system that has certain rules in cellular space and evolves in a discrete time dimension [33]. Structurally, it can be expressed as a quadratic group: $\mathrm{CA}=(\Omega, R, \Phi, f)$, where $\Omega$ denotes a cellular space, which is a collection of discrete spatial grids, $R$ represents a finite set of cell states, $\Phi$ denotes the set of neighboring cells that influence the state value of the initial cell at the next moment, and $f$ represents the local state-transition function, namely the evolution law [34]. 


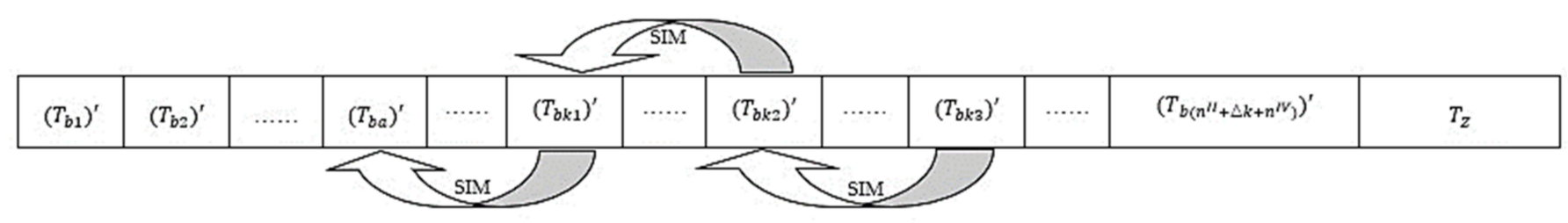

Figure 3. Allocation state at $t_{1}$.

As a computational model, the input of CA is the state of all cells in cell space $\Omega$ at $t_{0}$ (representing the past), and its state at $t_{1}$ (representing the present) is calculated as the output via the evolution law [35].

One-dimensional CA is generally considered to be capable of generalized computation [36]. Its structural features and computational principles have strong adaptability in form and connotation with the sustainable allocation of skilled workers in a project pool. In view of this, this paper is based on the theoretical framework of one-dimensional CA to construct a model for the sustainable allocation of work resumption. The theoretical model can be defined as follows.

Hypothesis 1 (H1). The set of the construction field space of each project Pa in the project pool is taken as cellular space $\Omega$.

Hypothesis 2 (H2). The set of allocation states that for each project and work type in the pool taken as $R, R=\{0,1,2\}$, where $\{0\}$ means that the current construction team is lost but can be dispatched from projects within a specific range (see Section 4.1, Step 2 for details) or projects with lower priority (see Section 4.1, Step 3 for details); $\{1\}$ means that the project and construction team are eligible for direct resumption without reconfiguration; $\{2\}$ means that the current construction team is lost and must be recruited from the labor market. Moreover, $S(k)=0$ means that the specific scope is too narrow and there are no more available teams, or that the project has the lowest priority, and there are no dispatchers.

Hypothesis 3 (H3). The set of energy level of lower-priority (or range-specific) project's construction team is taken as $\Phi$.

Hypothesis 4 (H4). The energy similarity function (SIM, and the time-cost function (Min(t)) are used as the core content in the local state-conversion function $f$. Based on the project priority, the energy similarity function SIM mainly solves two problems: (i) ensuring that the requirements of the project progress and the quality of the professional ability of the construction team are met; and (ii) considering the impacts of both the project priorities and pandemic in the project location on the priorities. The use of the time-cost function Min(t) mainly ensures the possibility and convenience of the allocation of the CA machine system [37]. The possibility is mainly reflected in the length of the pandemic waiting period for the main skilled workers in the construction team to resume work, while the convenience is mainly reflected in the speed of the transportation time for the main skilled workers of the construction team to resume work.

\subsubsection{Parametric Analysis of the Allocation Model}

The following discussion focuses on the energy similarity function, SIM, and the time-cost function, $\operatorname{Min}(t)$. 
Energy Similarity Function: SIM

By examining the connotation and application scope of various similarity functions, the weighted Euclidean distance $F(k)$ was chosen to determine the energy similarity; it is calculated as

$$
F(k)=\sqrt{\sum_{k=a+1}^{n} \varphi_{\mathrm{B}}\left|T_{b a}-T_{b k}\right|^{2}}(a, k \in N, a<k \leq n,)
$$

where $\varphi_{\mathrm{B}}$ refers to the weight vector of the energy-level index of the construction team. It is generally believed that the greater the difference of the energy-level index of each construction team in the project pool, the greater its influence on the energy level and the greater the proportion of weight and vice versa. Therefore, the weight can be characterized by the coefficient of variation of each indicator value, i.e., the standard deviation divided by the absolute value of the mean value.

$$
\varphi_{\mathrm{B}}=\sqrt{\frac{1}{n-1} \sum_{a=1}^{n}\left(T_{b a}-\frac{1}{n} \sum_{a=1}^{n} T_{b a}\right)^{2}} /\left|\frac{1}{n} \sum_{a=1}^{n} T_{b a}\right|(a \in N, a \leq n)
$$

The shorter the weighted Euclidean distance, the greater the energy similarity $s(k)$. Based on the substitution of Equation (8), the corresponding projects for construction teams with similar energy levels are as follows:

$$
K^{*}=\{k \mid \min \{F(k)\}\}
$$

To achieve a more comprehensive understanding of the energy level and similarity of the project pool, the weighted Euclidean distance between all projects can be calculated using the energy similarity matrix $F_{G_{i}}\left(K^{*}\right)$. When two or more projects have high $s(k)$ values for both the available and lost construction teams, and $F(k)$ is smaller and multiple $F(k)$ are similar in value, $K^{*}$ is not unique. In this case, there will be multiple target-project construction teams that can be invoked.

\section{Time-Cost Function: Min(t)}

In this paper, the decision-making issues of allocation or recruitment are discussed from the time-as-cost perspective after matching projects with construction team of comparable energy levels.

Assume that $t_{\mu}$ denotes the scheduling time and $t_{z}$ denotes the recruitment time. Consider that the starting point is a specific range (corresponding to situation II) or scheduling from a lower priority (corresponding to situations III and IV); the scheduling time is $t_{\mu}=t_{\mu 1}+t_{\mu 2}+t_{\mu 3}$, where $t_{\mu 1}$ represents the waiting time for the construction team to resume work (for situation II, let the waiting time for work resumption be 0 ), $t_{\mu 2}$ represents the travel time (based on the public transportation time) for the construction team to be dispatched from a specific range or low-priority project to a project of an equivalent energy level, and $t_{\mu 3}$ represents the time for adaptation to the work environment after the construction team reaches the project with an equivalent energy level. In the case of recruitment from the labor market, the actual recruitment time includes the recruitment search time, the net recruitment time, and the training and probation time, which are denoted as $t_{z}$. Consider each time that an energy level-equivalent project is found: when $t_{\mu} \leq t_{z}$, dispatch occurs; when $t_{\mu}>t_{z}$, dispatch does not occur, and the recruitment of workers from the labor market is based on the energy level of the lost working group. In particular, $t_{z}$ is related to the difficulties of recruitment in the labor market and the severity and control of the pandemic in each region. In a pandemic situation, considering that some regions will not yet have fully allowed the free movement of personnel, the future trend is subject to further observation. It is therefore preferable to solve the problem of the work resumption of 
personnel in high-priority projects of construction company in a short time via systematic scheduling and then to compensate for the shortfall from the external market.

Considering the complexity of the sustainable allocation of skilled workers for the work resumption in the pool, two more scenarios must be discussed.

i. Allocation of the lost workers in a project construction team for work resumption. At moment $\mathrm{t}_{1}$, if $\Delta F(k) \in(-10 \%, 10 \%), K^{*}$ is not unique, and multiple dispatch routes will be generated, and the route with the minimum combined number of dispatching instances of a project is regarded as the optimal route. When the comprehensive dispatching time is the same for both routes, the route with the fewest dispatching instances $N$ is optimal. At this time, the mathematical expression for the decision function of the optimal route of the work resumption of construction teams in a project pool is:

$$
\operatorname{MIN}\left(\sum t_{\mu}+t_{z}\right)=\operatorname{MIN}\left(\sum\left(t_{\mu 1}+t_{\mu 2}+t_{\mu 3}\right)+t_{z}\right),
$$

where $t_{\mu 1}$ depends on the status of the pandemic and the degree of pandemic control at the location of the dispatched team (or potential dispatched team) at a given time (if the conditions for the resumption of construction teams are met, $t_{\mu 1}=0$; if the conditions for the resumption of construction teams are met, but those for the resumption of projects are not met, $\left.t_{\mu 1}<0\right)$. Moreover, $t_{\mu 2}$ depends on the traffic and spatial distance between the project site and the location of the construction team at a certain time during the pandemic, and $t_{\mu 3}$ is the controllable reference time, which is set as a constant empirical value. The pandemic situation and site environment at the project location at a certain moment will affect the recruitment search time $t_{z}$. The decision function of the optimal route when the number of dispatching instances is equal to $N$ is:

$$
\operatorname{MIN}\left(\sum t_{\mu 1}+\sum t_{\mu 2}+N t_{\mu 3}+t_{z}\right)
$$

In the case of multiple routes, the route with a lower pandemic level, less frequent dispatching, and local dispatching should be chosen as the optimal route.

ii Allocation for certain types of construction teams for the resumption of projects for which the construction team has been lost. At $t_{1}$, there may be several lost construction teams of the same type in the project pool (the number of such teams is $L)$. According to the priority of $L$ projects with lost construction teams and the basic steps outlined in Section 4.1, it is possible to allocate them independently. However, if the lost team still faces multiple $K^{*}$ at a certain time, there may be mutual interference among the $L$ lost construction teams in the process of independent systematic allocation. Thus, the decision function of the optimal route is extended as:

$$
\operatorname{MIN}\left(\sum_{l} \sum_{\mu} t_{\mu}^{l}+L t_{z}\right)
$$

In summary, the evolutionary law of the CA of the project pool can be defined as

$$
f_{1}(a, b)=f_{0}(a, b)+|1-R(a, b)| *\left\{T_{b k_{i}}, \operatorname{Min}(t)\right\}
$$

where $a$ and $b$, respectively, denote the numbers of projects and work types:

$$
R(a, b)=\left\{\begin{array}{l}
0 \\
1 \\
2
\end{array}\right.
$$

Moreover, the energy level of the systematic allocation cells is as follows:

$$
T_{b k_{i}}=\left\{\begin{array}{c}
T_{b k_{i+1}} \\
T_{z}
\end{array} \quad(i \geq 0 \text { and } i \in N)\right.
$$




\section{Case Study and Demonstration}

\subsection{Case Overview and Prioritization Evaluation of the SGJ Construction}

A provincial capital city enterprise, SGJ Construction, was selected as the object of research. During the COVID-19 pandemic, the company had five projects under construction that were halted, the codes of which are respectively SX1, SX2, HB, SC, and GS. Based on online research and the compilation of data of the five projects in seven areas, including the remaining contract amount, profit per unit of time, remaining duration, quality, technical complexity, and impacts on short- and long-term strategies, as well as the combined opinions of project managers and corporate managers, the results were obtained as detailed in Table 6.

Table 6. Aggregate scores of priority indicators for each project in the SGJ.

\begin{tabular}{cccccc}
\hline \multirow{2}{*}{ Priority Indicator } & \multicolumn{5}{c}{ Project Pool } \\
\cline { 2 - 6 } & SX1 & SX2 & HB & SC & GS \\
\hline A1 & 0.66 & 0.22 & 0.38 & 0.27 & 0.70 \\
A2 & 0.50 & 0.40 & 0.60 & 0.85 & 0.72 \\
A3 & 0.30 & 0.70 & 0.50 & 0.50 & 0.50 \\
A4 & 0.50 & 0.50 & 0.50 & 0.80 & 0.70 \\
A5 & 0.50 & 0.60 & 0.50 & 0.50 & 0.55 \\
A6 & 0.60 & 0.45 & 0.50 & 0.55 & 0.70 \\
A7 & 0.50 & 0.70 & 0.50 & 0.70 & 0.80 \\
\hline
\end{tabular}

According to Equations (2) and (3), the weight value $W_{j}$ of each priority indicator was obtained by MATLAB 2015a software as follows:

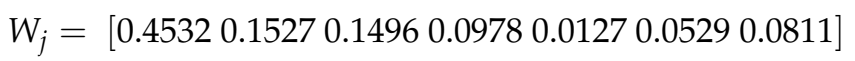

Moreover, the relative priority of each project was calculated as follows:

$$
I_{i}=\left[\begin{array}{lll}
0.21970 .1519 & 0.17780 .1837 & 0.2669
\end{array}\right]
$$

From these results, it is evident that the five projects of SGJ Construction that were halted during the pandemic are not very difficult to construct, so the indicator of technical complexity was found to have the lowest weight. The indicator of the remaining contract amount was found to have the highest weight due to the variety of projects and the large differences in the remaining contract amounts. Moreover, the profit per unit of time and duration requirements are related, and their weights are equal. Finally, the impact on long-term strategies was found to have a higher index weight than the impact on short-term strategies.

The five projects of SGJ Construction at moment $t_{0}$ (before pandemic control) were initially ranked according to Equation (5), as shown in Table 7.

Table 7. The initial prioritization ranks of projects in the SGJ.

\begin{tabular}{ccccc}
\hline & \multicolumn{4}{l}{ Initial Prioritization Rank of Project Pools } \\
GS & SX1 & SC & HB & SX2 \\
\hline$P_{1}$ & $P_{2}$ & $P_{3}$ & $P_{4}$ & $P_{5}$ \\
\hline
\end{tabular}

The pandemic impact indicators of the places where the projects were located at moment $t_{1}$ (after pandemic control; 29 February 2020) were obtained according to Equation (1), as presented in Table 8. Then, according to Equations (4) and (6), the five projects of SGJ Construction during the pandemic were ranked, as reported in Table 9. 
Table 8. Pandemic impact indicators and revised priority score for the SGJ Construction locations.

\begin{tabular}{cccccc}
\hline Project Code & SX1 & SX2 & HB & SC & GS \\
\hline$C_{i}$ & 0.05 & 0.05 & 0.81 & 0.25 & 0.03 \\
$I_{i}^{\prime}$ & 0.2090 & 0.1445 & 0.0791 & 0.1431 & 0.2590 \\
\hline
\end{tabular}

Table 9. The revised priority ranking of projects in the SGJ during pandemic.

\begin{tabular}{ccccc}
\hline & \multicolumn{4}{c}{ Revised Prioritization Ranking of Project Pools } \\
GS & SX1 & SX2 & SC & HB \\
\hline$\left(P_{1}\right)^{\prime}$ & $\left(P_{2}\right)^{\prime}$ & $\left(P_{3}\right)^{\prime}$ & $\left(P_{4}\right)^{\prime}$ & $\left(P_{5}\right)^{\prime}$ \\
\hline
\end{tabular}

\subsection{Sustainable Allocation of the SGJ Construction Teams for Work Resumption}

The sizes, skill levels, and experience values of the main in-service work types and construction teams of the five projects at moment $t_{0}$ (before pandemic control) were investigated, and the results are exhibited in Table 10. The sustainable allocation of the SGJ Construction teams to resume work was subsequently analyzed by taking reinforcement workers as an example.

Table 10. The initial allocation of the SGJ Construction teams to the energy level of the main work.

\begin{tabular}{cccccc}
\hline \multirow{2}{*}{ Type of Work } & \multicolumn{5}{c}{ Project Pool } \\
\cline { 2 - 6 } & $\boldsymbol{G S}\left(\boldsymbol{P}_{1}\right)\left(\boldsymbol{P}_{1}\right)^{\prime}$ & $\boldsymbol{S X} \mathbf{X}\left(\boldsymbol{P}_{2}\right)\left(\boldsymbol{P}_{2}\right)^{\prime}$ & $\boldsymbol{S C}\left(\boldsymbol{P}_{3}\right)\left(\boldsymbol{P}_{4}\right)^{\prime}$ & $\boldsymbol{H B}\left(\boldsymbol{P}_{4}\right)\left(\boldsymbol{P}_{5}\right)^{\prime}$ & $\boldsymbol{S X} \mathbf{2}\left(\boldsymbol{P}_{5}\right)\left(\boldsymbol{P}_{3}\right)^{\prime}$ \\
\hline Carpenter, $G_{1}$ & $T_{11}$ & $T_{12}$ & $T_{13}$ & $T_{14}$ & $T_{15}$ \\
\hline $\begin{array}{c}\text { Reinforcement } \\
\text { worker, } G_{2}\end{array}$ & $T_{21}$ & $T_{22}$ & $T_{23}$ & $T_{24}$ & $T_{25}$ \\
\hline Concrete worker, $G_{3}$ & $T_{31}$ & $T_{32}$ & $T_{33}$ & $T_{34}$ & $T_{35}$ \\
\hline Masonry worker, $G_{4}$ & $T_{41}$ & $T_{42}$ & $T_{43}$ & $T_{44}$ & $T_{45}$ \\
\hline Plasterer, $G_{5}$ & $T_{51}$ & $T_{52}$ & $T_{53}$ & $T_{54}$ & $T_{55}$ \\
\hline Scaffolder, $G_{6}$ & $T_{61}$ & $T_{62}$ & $T_{63}$ & $T_{64}$ & $T_{65}$ \\
\hline$\ldots$ & $\ldots$ & $\ldots$ & $\ldots$ & $\ldots$ & $\ldots$ \\
\hline
\end{tabular}

The work resumption of the reinforcement workers for each project at moment $t_{1}$ (29 February 2020) is presented in Table 11.

Table 11. The work resumption of the reinforcement workers in project pool during pandemic.

\begin{tabular}{ccccc}
\hline Situation & Resumption of Projects & $\begin{array}{c}\text { Resumption of } \\
\text { Construction Teams }\end{array}$ & Project Set & Construction Team Set \\
\hline I & $\begin{array}{c}\text { Conditions are in place to } \\
\text { resume projects }\end{array}$ & $\begin{array}{c}\text { Conditions are in place to } \\
\text { resume construction teams }\end{array}$ & $U^{I}=\{\mathrm{SX} 1\}$ & $G^{I}=\left\{T_{22}\right\}$ \\
\hline II & $\begin{array}{c}\text { Conditions are in place to } \\
\text { resume projects }\end{array}$ & $\begin{array}{c}\text { Failure to meet conditions } \\
\text { for the resumption of } \\
\text { construction teams }\end{array}$ & $U^{I I}=\{\mathrm{GS}, \mathrm{SX} 2\}$ & $G^{I I}=\left\{T_{21}, T_{25}\right\}$ \\
\hline III & $\begin{array}{c}\text { Failure to meet conditions } \\
\text { for the resumption } \\
\text { of projects }\end{array}$ & $\begin{array}{c}\text { Conditions are in place to } \\
\text { resume construction teams }\end{array}$ & $U^{I I I}=\{\mathrm{SC}, \mathrm{HB}\}$ & $G^{I I I}=\left\{T_{23}, T_{24}\right\}$ \\
\hline
\end{tabular}


According to Equations (11) and (12), MATLAB was employed to calculate the weighted Euclidean distance of each reinforcement worker $\left(G_{2}\right)$ for each project under the initial and corrected priority rankings, respectively.

$$
\begin{aligned}
\mathrm{F}_{G_{2}}\left(K^{*}\right)= & {\left[\begin{array}{ccccc}
0 & 1.9324 & 3.2093 & 2.7602 & 2.6053 \\
1.9324 & 0 & 4.4344 & 4.5692 & 3.8199 \\
3.2093 & 4.4344 & 0 & 1.9874 & 0.6247 \\
2.7602 & 4.5692 & 1.9874 & 0 & 1.8867 \\
2.6053 & 3.8199 & 0.6247 & \mathbf{1 . 8 8 6 7} & 0
\end{array}\right] } \\
\mathrm{F}_{\mathrm{G}_{2}}^{\prime}\left(K^{*}\right)= & {\left[\begin{array}{ccccc}
0 & 1.9324 & 2.6053 & 3.2093 & 2.7602 \\
1.9324 & 0 & 3.8199 & 4.4344 & 4.5692 \\
2.6053 & 3.8199 & 0 & 0.6247 & 1.8867 \\
\mathbf{3 . 2 0 9 3} & 4.4344 & \mathbf{0 . 6 2 4 7} & 0 & 1.9874 \\
\mathbf{2 . 7 6 0 2} & 4.5692 & 1.8867 & 1.9874 & 0
\end{array}\right] }
\end{aligned}
$$

For situation II, according to Equation (13), a construction team in $G^{I I I}$ with a high energy similarity (minimum weighted Euclidean distance) is selected out with the rank of project priority, which is GS $\left(P_{1}\right)$ followed by SX2 $\left(P_{2}\right)$. Based on $F_{G_{2}}\left(K^{*}\right)$, the reinforcement construction team $T_{24}$ should first be allocated to the project GS $\left(P_{1}\right)$, which has already met the conditions for the resumption of projects; then, the reinforcement construction team $T_{23}$ of project SC $\left(P_{3}\right)$ should be allocated to project SX2 $\left(P_{5}\right)$, which has already met the conditions for the resumption of projects. For situation III, based on the order of correction priority in the pandemic, the construction teams from $G^{I I}$ with high energy similarity (minimum weighted Euclidean distance) should be prepared for projects that have not yet met the resumption conditions, such as $\mathrm{SC}\left(P_{4}\right)^{\prime}$ and $\mathrm{HB}\left(P_{5}\right)^{\prime}$. Based on $F_{G_{2}}^{\prime}\left(K^{*}\right)$, first, the reinforcement construction team $T_{25}$ in the pandemic waiting period should be prepared for the project GS $\left(P_{4}\right)$, which has not met the conditions for resumption; then, the reinforcement construction team $T_{21}$ in the pandemic waiting period should be prepared for the project GS $\left(P_{5}\right)$, which has not met the conditions for resumption.

In this process, $\Delta F(k) \notin(-10 \%, 10 \%), K^{*}$ is unique, and multi-routines and the time-cost function $\operatorname{Min}(t)$ are not considered.

In summary, among the five projects of SGJ Construction, two meet the conditions for project resumption, but not the conditions for the resumption of the previous construction team, which is a contrary situation to that of the two other projects. These opposing groups can complement each other. To stabilize employment, considering that $t_{\mu}<t_{z}$ is fully met, no external recruitment should be considered at this time. Based on the allocation model of work resumption in project pools, the following results can be obtained:

i. The cells involved in the sustainable allocation include $G_{2}\left(T_{21}, T_{25} ; T_{23}, T_{24}\right)$ and $G_{2}^{\prime}$ $\left(T_{23}, T_{24} ; T_{25}, T_{21}\right)$;

ii. The energy level of each cell involved in the sustainable allocation is $G_{2}\left(T_{21}=T_{23}\right.$; $\left.T_{25}=T_{24}\right)$ and $G_{2}^{\prime}\left(T_{23}=T_{25} ; T_{24}=T_{21}\right)$;

iii. The evolution process of the cellular matrix is as follows.

$$
A C_{1}=\left[\begin{array}{lllll}
1 & 1 & 1 & 1 & 1 \\
0 & 1 & 1 & 1 & 0 \\
1 & 1 & 1 & 1 & 1 \\
1 & 1 & 1 & 1 & 1 \\
1 & 1 & 1 & 1 & 1 \\
1 & 1 & 1 & 1 & 1 \\
1 & 1 & 1 & 1 & 1
\end{array}\right] \rightarrow A C_{1}=\left[\begin{array}{lllll}
1 & 1 & 1 & 1 & 1 \\
1 & 1 & 0 & 0 & 1 \\
1 & 1 & 1 & 1 & 1 \\
1 & 1 & 1 & 1 & 1 \\
1 & 1 & 1 & 1 & 1 \\
1 & 1 & 1 & 1 & 1 \\
1 & 1 & 1 & 1 & 1
\end{array}\right] \rightarrow A C_{1}=\left[\begin{array}{lllll}
1 & 1 & 1 & 1 & 1 \\
1 & 1 & 1 & 1 & 1 \\
1 & 1 & 1 & 1 & 1 \\
1 & 1 & 1 & 1 & 1 \\
1 & 1 & 1 & 1 & 1 \\
1 & 1 & 1 & 1 & 1 \\
1 & 1 & 1 & 1 & 1
\end{array}\right]
$$

The evolution of this cellular matrix is the process of the sustainable allocation of skilled workers for the work resumption in project pools of the SGJ Construction. 


\subsection{Result and Discussion}

Results demonstrate the post-pandemic work resumption of five ongoing projects in SGJ Construction. Figures 4 and 5 display the initial project prioritization and the optimized project prioritization in pandemic, respectively. Zones with darker colors show higher priority of project resumption. Figures 6 and 7 present the work resumption situation without and with sustainable allocation of reinforcement workers. Green indicates the resumption of project and construction teams in this area. The red marks indicate that the workers are temporarily unable to resume work.

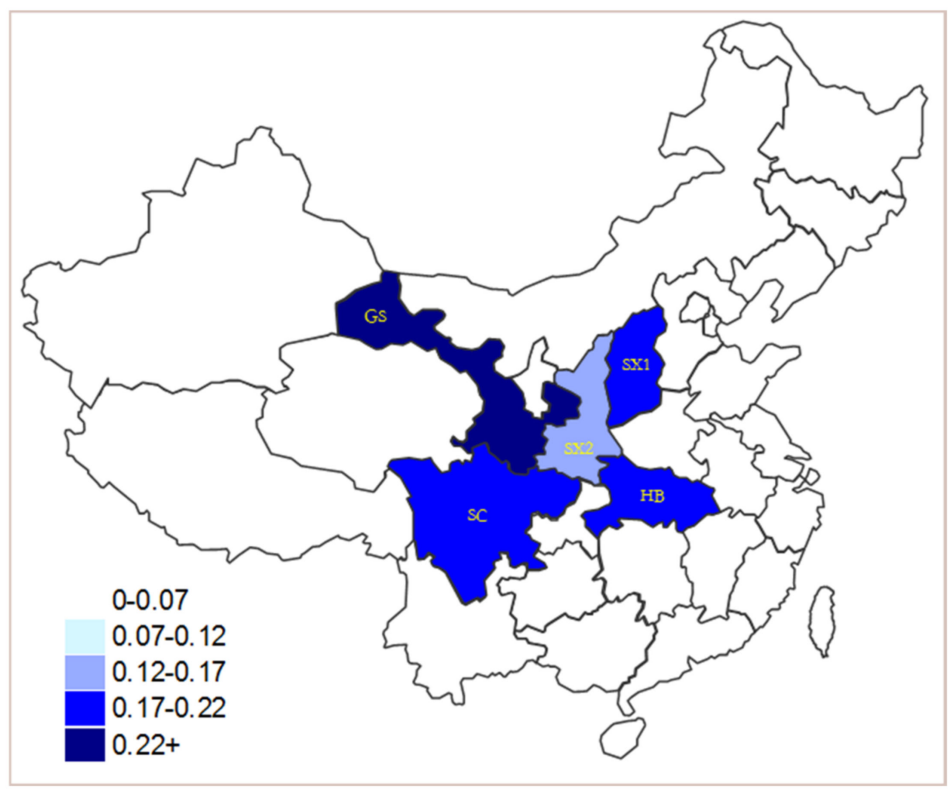

Figure 4. The initial project prioritization.

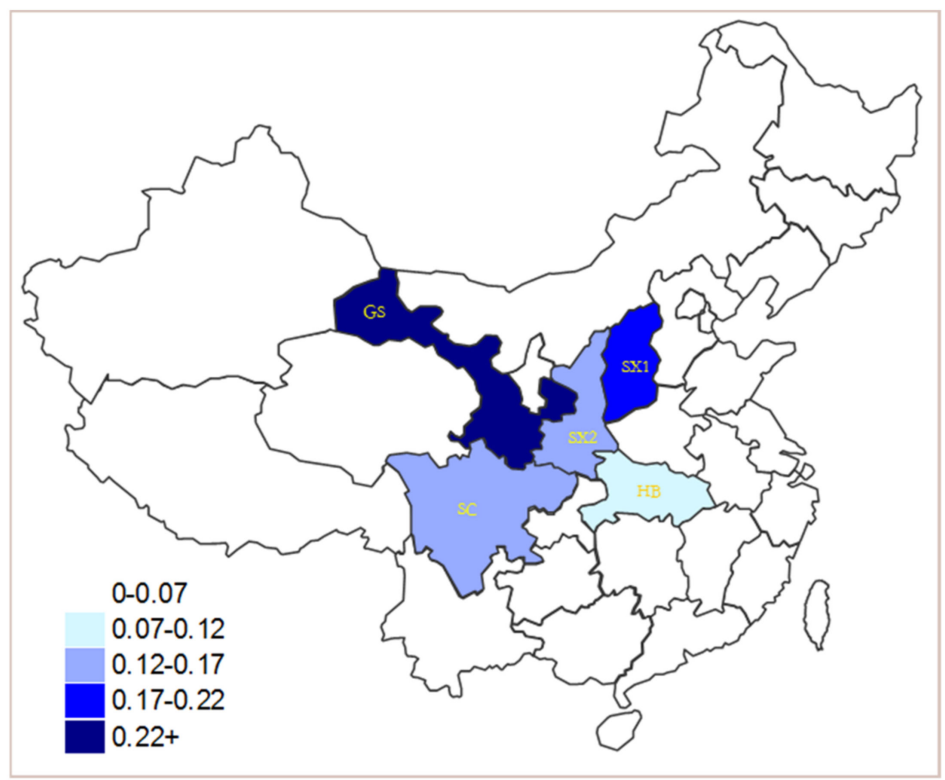

Figure 5. The optimized project prioritization in pandemic. 


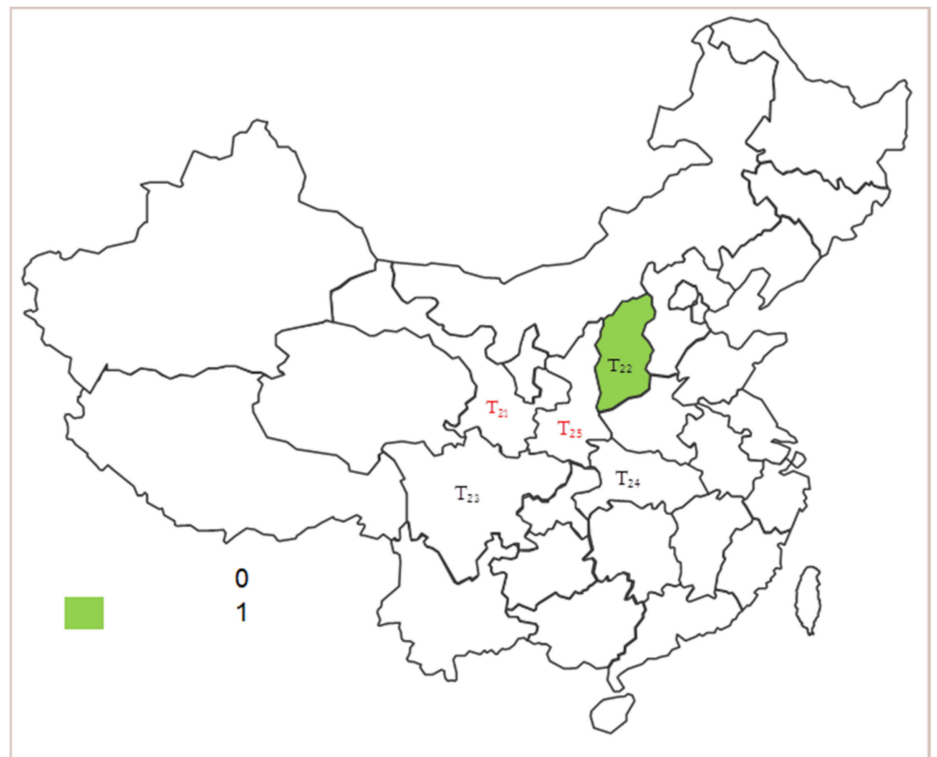

Figure 6. Work resumption without sustainable allocation of the reinforcement workers during pandemic.

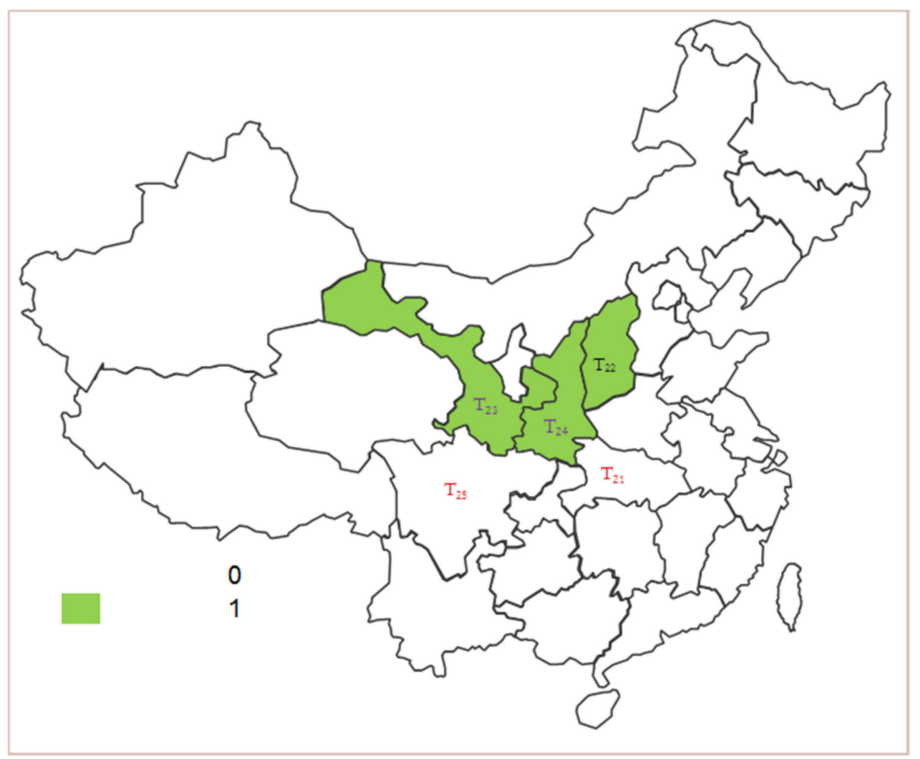

Figure 7. Work resumption with sustainable allocation of the reinforcement workers during pandemic.

The comparison between Figures 4 and 5 confirms that pandemic has affected project prioritization. There are two reasons for that. One is due to compulsory administrative order to shut down by the local government; the other is from a voluntary close as corporate social responsibility. For example, Project HB ran with medium priority for SGJ in Figure 4. But, under pandemic with high risk, the government's mandatory lockdown measures continued until early April 2020. It was almost impossible to resume work in the immediate period $\left(t_{1}\right)$. Therefore, Project HB degraded to the lowest priority during pandemic in Figure 5. Project SC ran with higher priority for SGJ in Figure 4. Under pandemic with medium risk, local government agreed to work resumption of construction on 17 February. But considering the rise of raw materials and long-distance migration of major skilled workers, the SGJ decided to delay the start. Thus, Project SC degraded to the medium priority during pandemic in Figure 5.

The comparison between Figures 6 and 7 shows that our allocation model improves the work resumption for SGJ and makes it sustainable. Construction teams that meet conditions for work resumption should be fully employed. Construction teams that fail 
conditions for work resumption should be allocated for the projects that did not start in the immediate period $\left(t_{1}\right)$. For example, Project SX1 is the only project that qualified for both resumption of production and resumption of reinforcement workers in Figure 6. Through sustainable allocation (Section 4), reinforcement construction teams $T_{23}$ and $T_{24}$ can be dispatched to Project GS and SX2 separately. Workers stranded due to the pandemic in $T_{21}$ and $T_{25}$ should be prepared for future resumption. Then, Project SX1, GS and SX2 should resume construction, and Teams $T_{22}, T_{23}$, and $T_{24}$ should resume work in Figure 7.

\section{Conclusions}

The World Health Organization (WHO) states that impacts from COVID-19 will last for some time. Countries will have to repeat the control-resumption-control cycle to tackle the pandemic influence until it is completely over. Industries should achieve a balance between pandemic prevention and work resumption. Optimal decisions to production resumption and workforce allocation are primary for construction companies in the new normal.

This paper reports a workforce allocation model that considers four types of work resumption, the availability of construction teams, and the general project priority. The model produces optimal construction-team allocation plans. The model can guide the deployment of sustainable production resumption and abides by pandemic prevention and control policies. The model provides implications for other countries or other industries on sustainable allocation of work resumption during the pandemic.

This paper has some limitations. First, the evaluation index and allocation model can reflect on the systematic evolution of the work resumption in a project pool. Their robustness needs further case validation in practice. Second, the allocation model emphasizes the allocation method of sustainable employment in regard to social responsibility but lacks in-depth analysis on the allocation efficiency and allocation cost from the perspective of construction companies. Some factors are not included, for example, the willingness of skilled workers or government subsidies. Third, this paper uses a medium-sized construction company for case study whose results may not apply to smaller or bigger companies.

Future research can refine the allocation model to include data from other construction companies, which may lead different types of projects to work resumption. Future research can also investigate the social and economic benefits of sustainable allocation from the perspective of government and construction company under pandemic, focusing on time, cost, and labor reserve in different regions.

Author Contributions: Conceptualization, L.W.; methodology, L.W.; software, L.W.; validation, D.Z.; formal analysis, L.W.; investigation, L.W.; resources, L.W.; data curation, L.W.; writing—original draft preparation, L.W.; writing-review and editing, Y.Z.; visualization, L.W.; supervision, D.Z.; project administration, L.W.; funding acquisition, L.W. All authors have read and agreed to the published version of the manuscript.

Funding: This work was supported by the Provincial fund of Shaanxi in China under grant number $2020 Z 182$ and New Urbanization Special Research Fund "COVID-19 Emergency Study" Special Project (number XGYJ202006).

Institutional Review Board Statement: The study was conducted according to the guidelines of the Declaration of Helsinki, and Institutional review board approval of our university was obtained for this study.

Informed Consent Statement: Informed consent was obtained from all subjects involved in the study.

Data Availability Statement: The data of pandemic comes from the link https://voice.baidu.com/ act/newpneumonia/newpneumonia/; the data of Chinese policies come from the links http:/ / www. mohrss.gov.cn/gkml/zcfg/gfxwj/202002/t20200207_358328.html and http://www.gov.cn/xinwen/ 2020-02/18/content_5480514.htm; the data of example come from the head of SGJ Construction.

Acknowledgments: Thanks to Shaanxi Department of Housing and Construction for its support on “COVID-19 Emergency Study" project, and thanks to SGJ Construction for its data sharing.

Conflicts of Interest: The authors declare no conflict of interest. 


\section{References}

1. Liu, J.; Liu, Y.S.; Chen, X. An analysis of the influencing factors, development trend and countermeasures of labor cost rising in construction industry. J. Beijing Jiaotong Univ. 2015, 14, 45.

2. Ministry of Human Resources and Social Security of the People's Republic of China. Opinions on Doing a Good Job in Stabilizing Labor Relations during the Prevention and Control of the Covid-19 Pandemic and Supporting Enterprises to Work Resumption. Available online: http://www.mohrss.gov.cn/gkml/zcfg/gfxwj/202002/t20200207_358328.html (accessed on 29 February 2020).

3. Castillo-Salazar, J.A.; Landa-Silva, D.; Qu, R. Workforce scheduling and routing problems: Literature survey and computational study. Ann. Oper. Res. 2016, 239, 39-67. [CrossRef]

4. Persad, K.R.; O'Connor, J.T.; Varghese, K. Forecasting engineering manpower requirements for highway preconstruction activities. J. Manag. Eng. 1995, 11, 41-47. [CrossRef]

5. Whang, S.W.; Flanagan, R.; Kim, S.; Kim, S. Contractor-led critical design management factors in high-rise building projects involving multinational design teams. J. Constr. Eng. Manag. 2016, 143, 06016009. [CrossRef]

6. Zhang, X.; Luo, W.; Cai, Y. Assigning crowdsourcing project to crowdsourcing workers: A risky multi-objective optimization model. Syst. Eng. 2018, 36, 53-60.

7. Yang, W.J.; Kim, Y.S. Manpower allocation model for construction site office engineers based on inherent technical risks. KSCE J. Civ. Eng. 2019, 23, 947-957. [CrossRef]

8. Ballesteros-Pérez, P.; González-Cruz, M.C.; Fernandez-Diego, M. Human resource allocation management in multiple projects using sociometric techniques. Int. J. Proj. Manag. 2012, 30, 901-913. [CrossRef]

9. Liao, P.C.; Liu, B.; Wang, Y.; Wang, X.; Ganbat, T. Work paradigm as a moderator between cognitive factors and behaviors-A comparison of mechanical and rebar workers. KSCE J. Civ. Eng. 2017, 21, 2514-2525. [CrossRef]

10. Shahbazi, B.; Akbarnezhad, A.; Rey, D.; Fini, A.; Loosemore, M. Optimization of job allocation in construction organizations to maximize workers' career development opportunities. J. Constr. Eng. Manag. 2019, 145, 04019036. [CrossRef]

11. Mats, E.; Anna, J. The resource allocation syndrome: The prime challenge of multi-project management. Int. J. Proj. Manag. 2003, 21, 403-409.

12. Yoshimura, M.; Fujimi, Y.; Nishiwa-Ki, S. Human resource allocation optimization for multiple development projects. Trans. Jpn. Soc. Mech. Eng. 2005, 71, 677-684. [CrossRef]

13. Chen, J.; Wang, S. Method research for dynamic multi-project human resource allocation based on multidimensional model. In Proceedings of the 2011 International Conference on Information Management, Innovation Management and Industrial Engineering, Shenzhen, China, 26-27 November 2011; Volume 3, pp. 78-81.

14. El-Abbasy, M.S.; Elazouni, A.; Zayed, T. Generic scheduling optimization model for multiple construction projects. J. Comput. Civ. Eng. 2017, 31, 04017003. [CrossRef]

15. Yong, Z.; Zhigao, C.; Zhong, Z. Resource allocation model and strategy research of large-scale construction projects: System dynamics modeling and simulation. Chin. Manag. Sci. 2016, 24, 125-132.

16. Hou, Y.H.; Rao, W.Z.; Hao, M. Study on multi-project human resources allocation of engineering construction enterprise-based on the perspective of competence and two-level optimization. Oper. Res. Manag. Sci. 2017, 26, 192-199.

17. Florez, L. Crew allocation system for the masonry industry. Comput. Aided Civ. Infrastruct. Eng. 2017, 32, 874-889. [CrossRef]

18. Mo, Y.; Zhao, D.; Du, J.; Syal, M.; Aziz, A.; Li, H. Automated staff assignment for building maintenance using natural language processing. Autom. Constr. 2020, 113, 103150. [CrossRef]

19. Koch, C.; Marton, J. Implementing multi-skilled teams on a construction site-Developing a Scandinavian model? In Proceedings of the 18th Annual ARCOM Conference, Newcastle upon Tyne, UK, 2-4 September 2002; pp. 247-256.

20. Thomas, H.R.; Horman, M.J. Fundamental principles of workforce management. J. Constr. Eng. Manag. 2006, 132, 97-104. [CrossRef]

21. Walter, M.; Zimmermann, J. On a multi-project staffing problem with heterogeneously skilled workers. Oper. Res. Proc. 2012, 127, 489-494.

22. Li, W.; Peng, L.; Zhang, D. Analysis on the mechanism of the heterogeneity of project construction team leaders affecting post competence. J. Railw. Sci. Eng. 2019, 16, 1857-1864.

23. Anoshkina, Y.; Meisel, F. Technician teaming and routing with service-, cost- and fairness-objectives. Comput. Ind. Eng. 2019, 135, 868-880. [CrossRef]

24. Drezet, L.; Billaut, J. A project scheduling problem with labor constraints and time-dependent activities requirements. Eur. J. Oper. Res. 2008, 112, 217-225.

25. Nasirian, A.; Arashpour, M.; Abbasi, B.; Zavadskas, E.K.; Akbarnezhad, A. Skill set configuration in prefabricated construction: Hybrid optimization and multicriteria decision-making approach. J. Constr. Eng. Manag. 2019, 145, 04019050. [CrossRef]

26. Nasirian, A.; Arashpour, M.; Abbasi, B. Critical literature review of labor multiskilling in construction. J. Constr. Eng. Manag. 2019, 145, 04018113. [CrossRef]

27. Sarihi, M.; Shahhosseini, V.; Banki, M.T. Multiskilled project management workforce assignment across multiple projects regarding competency. J. Constr. Eng. Manag. 2020, 146, 04020134. [CrossRef]

28. Baidu. Real-Time Big Data Report of the Pandemic. Available online: https://voice.baidu.com/act/newpneumonia/ newpneumonia/ (accessed on 29 February 2020). 
29. State Council of the Central People's Government of the People's Republic of China. Guidance Opinions on the Prevention and Control of New Coronary Pneumonia Pandemic through Scientific Prevention and Precise Measures in Zones and Grades. Available online: http:/ / www.gov.cn/xinwen/2020-02/18/content_5480514.htm (accessed on 29 February 2020).

30. Shannon, C.E. Prediction and Entropy of Printed English; Oxford University Press: Oxford, UK, 1951.

31. Bi, A.; Luo, Z.; Wang, X.; Sun, Y. Extension model weighted by vague sets and entropy method and its engineering application. Syst. Eng. 2018, 36, 112-120.

32. Wang, L.-Y. A research to build and operate the BIM-L database for supply-side reform of skilled workers in construction industry. J. Xi'an Univ. Arch. Tech. 2020, 39, 67-73.

33. Chao, X.; Yang, Y.; Zhou, Z. Simulation of risk transfer in enterprise group based on Cellular Automaton. Chin. J. Manag. Sci. 2012, 20, 144-150.

34. Wolfram, S. Statistical mechanics of Cellular Automaton. Rev. Mod. Phys. 1983, 55, 601-643. [CrossRef]

35. Rong, L.; Zhou, P.; Rong, Z. A consequence deduction model of emergency based on one-dimensional cellular automata. Oper. Res. Manag. Sci. 2015, 24, 158-160.

36. Lindgren, K.; Mats Nordahl, G. Universal computation in simple one-dimensional Cellular Automaton. Complex Syst. 1990, 4, 299-318.

37. Bosurgi, G.; Pellegrino, O.; Sollazzo, G. Project duration evaluated using affine arithmetic. Period. Polytech. Civ. Eng. 2017, 61, 412-420. [CrossRef] 